\title{
Pengembangan dan Pengujian Aplikasi Website Career Center ITERA
}

\author{
Agis Tri wahyuji ${ }^{1}$, Hartanto Tantriawan ${ }^{1}$, Hira Laksmiwati Soemitro² \\ ${ }^{1}$ Jurusan Teknik Elektro, Informatika dan Sistem Fisis, Teknik Informatika, Institut Teknologi Sumatera, \\ Lampung Selatan, Indonesia \\ ${ }^{2}$ Sekolah Teknik Elektro dan Informatika, Teknik Informatika, Institut Teknologi Bandung, Bandung, Indonesia \\ Email: ${ }^{1}$ Wahyujiat@gmail.com, ${ }^{2}$ Hartanto.tantriawan@if.itera.ac.id, ${ }^{3} \mathrm{Hira@informatika.org}$ \\ *Corresponding author, e-mail: ${ }^{2}$ Hartanto.tantriawan@if.itera.ac.id, ${ }^{1}$ Wahyujiat@gmail.com
}

\begin{abstract}
Abstrak-Teknologi di era dunia digital telah menjadi sesuatu yang sangat dekat untuk semua kalangan, termasuk para calon tenaga kerja yang mencari informasi tentang lowongan pekerjaan. Dalam perkembangannya telah banyak digunakan sistem berbasis web. Seperti halnya manajemen sistem informasi dalam bidang pendidikan khususnya perguruan tinggi, suatu instansi pendidikan tertinggi tersebut memerlukan suatu manajemen sistem informasi yang dapat diakses dengan mudah, tidak membutuhkan waktu yang lama dan dapat menekan biaya operasional. sulitnya mendapatkan pekerjaan seakan jadi masalah yang tidak pernah habisnya. Tingkat pendidikan yang tinggi dan kelulusan yang baik ternyata tidak bisa di jadikan jaminan untuk mendapatkan pekerjaan yang sesuai dengan latar belakang dan keinginan. Hal ini terbukti dari tingginya tingkat pengangguran terbuka atau pengangguran akademik yang ada di Indonesia. Seiring dengan berjalannya waktu, Institut Teknologi Sumatera (ITERA) telah meluluskan lulusan dengan berbagai keahlian yang dapat bersaing dengan para lulusanlulusan dari perguruan tinggi lain. Akan tetapi hingga saat ini Insitut Teknologi Sumatera (ITERA) belum memiliki sistem yang dapat memberikan informasi lowongan pekerjaan dan pengembangan karir bagi alumni yang baru lulus sehingga menyebabkan para lulusan berusaha sendiri dalam menemukan dan mencari lowongan pekerjaan, dan juga membutuhkan waktu dalam mendapatkan pekerjaan impian yang mengakibatkan lulusan mengangur dalam jangka waktu yang cukup lama. ITERA telah memfasilitasi lulusan untuk mendapatkan pekerjaan dengan mengadakan job fair, akan tetapi dirasa belum efektif dikarenakan lulusan yang ikut serta didalamnya sedikit, yaitu hanya $40 \%$ dari total lulusan yang berstatus fresh graduate. Dalam pengembangan dan pengujian aplikasi ini, menggunakan metodologi pengembangan System Development Life Cycle (SDLC) dengan mengacu pada model waterfall serta UML sebagai toolsnya. Sedangkan bahasa pemrograman yang digunakan adalah Framework Codeigniter, Bootstrap, dan Xampp sebagai server local dan pengujian aplikasi ini menggunakan teknik black box dengan metode equivalence partititoning dan menggunakan teknik white box dengan Katalon Studio sebagai alatnya. Pengujian dilakukan secara localhost. Hasil pengujian menunjukkan bahwa pengembangan website career center ini menunjukan bahwa aplikasi dapat berjalan dengan baik sesuai dengan yang diharapkan dalam memberikan informasi mengenai lowongan kerja.
\end{abstract}

Kata Kunci: ITERA, Waterfall, Pusat Karir, Pengujian, Lowongan Kerja.

\begin{abstract}
Technology in the digital era has become very close to all people, including prospective workers looking for information about job vacancies. In its development, many web-based systems have been used. Like the management of information systems in the field of education, especially universities, a higher education institution requires a management information system that can be accessed easily, does not require a long time, and can reduce operational costs. the difficulty of getting a job seemed to be a never-ending problem. It turns out that high levels of education and good graduation cannot be used as a guarantee for getting a job that matches your background and desires. This is evident from the high level of open unemployment or academic unemployment in Indonesia. Over time, the Sumatra Institute of Technology (ITERA) has graduated graduates with various skills that can compete with graduates from other universities. However, until now the Sumatra Institute of Technology (ITERA) does not yet have a system that can provide information on job vacancies and career development for newly graduated alumni, causing graduates to try on their own in finding and looking for vacancy job, and also takes time to get a dream job. produce graduates being unemployed for a long period of time. ITERA has facilitated graduates to get a job by holding job fairs, but it is deemed ineffective because of the few graduates who take part in it, namely only $40 \%$ of the total graduates are fresh graduates. In developing and testing this application, using the System Development Life Cycle (SDLC) development methodology regarding the waterfall model and UML as tools. While the programming language used is the Codeigniter Framework, Bootstrap, and Xampp as a local server, and testing this application uses the black box technique with the equivalence partitioning method and uses the white box technique with Katalon Studio as a tool. Testing is done on localhost. The test results show that the development of the career center website shows that the application can run well as expected in providing information about job vacancies.
\end{abstract}

Keywords: ITERA, Waterfall, Career Center, Testing, Job Vacancies 


\section{PENDAHULUAN}

\subsection{Latar Belakang}

Perkembangan teknologi informasi dan komunikasi telah dimanfaatkan di berbagai bidang kehidupan, seiring perkembangan zaman, teknologi informasi dan komunikasi merupakan sarana yang dibutuhkan dalam suatu pengerjaan tugas, teknologi informasi dan komunikasi yang terkait bisa memberikan harapan pada semua orang untuk pekerjaannya dan juga telah mewarnai aktivitas masyarakat sehari-hari, dengan teknologi tersebut akan memudahkan dalam menyimpan, mengolah dan menampilkan sebuah data[1].

Saat ini teknologi informasi berkembang dengan sangat pesat sehingga untuk berkomunikasi dan mendapatkan informasi tidak lagi terbatas oleh jarak dan waktu. Perkembangan teknologi komputer yang terus berlanjut membawa dampak pada proses pengolahan data dan penyampaian informasi sesuai kebutuhan. Sehingga setiap hal dapat dilakukan dengan lebih cepat juga praktis. Dalam mencari informasi lowongan pekerjaan, pelamar biasanya menggunakan cara manual, yaitu dengan mendatangi perusahaan untuk melihat pengumuman yang berisi lowongan pekerjaan, melakukan pencarian di media web, sosial media, dan aplikasi pengirm pesan instan. Proses tersebut memiliki kekurangan karena pelamar harus mendatangi perusahaan yang dituju dengan membawa berkas persyaratan, surat lamaran dan persyaratan lainnya yang menggunakan banyak kertas serta adanya kemungkinan persyaratan yang dibawa akan mudah sobek, terkena basah ketika sampai diperusahaan. Alternatif lainnya biasanya dengan mengirimkan melalui email yang tersedia pad abrosul loeongan pekerjaan yang sedang dibuka, akna tetapi juga memiliki kekuranagn yaitu akan sulit dibaca oleh perusahaan karena banyaknya pelamar yang lain juga mendaftar pekerjaan tersebut[2].

Seiring perkembangan teknologi, web merupakan penerapan penyajian informasi yang sampai saat ini merupakan media yang paling banyak diakses oleh manusia. Dengan demikian dapat dikatakan bahwa manusia menjadi tergantung pada media tersebut untuk dapat memenuhi kebutuhannya akan informasi[3]. Teknologi di era dunia digital telah menjadi sesuatu yang sangat dekat untuk semua kalangan termasuk para calon tenaga kerja yang mencari informasi tentang lowongan pekerjaan. Dalam perkembangannya telah banyak digunakan sistem berbasis web[4]. Seperti halnya manajemen sistem informasi dalam bidang pendidikan khususnya perguruan tinggi, suatu instansi pendidikan tertinggi tersebut memerlukan suatu manajemen sistem informasi yang dapat diakses dengan mudah, tidak membutuhkan waktu yang lama dan dapat menekan biaya operasional[5].

Sulitnya mendapatkan pekerjaan seakan jadi masalah yang tidak pernah habisnya. Tingkat pendidikan yang tinggi dan kelulusan yang baik ternyata tidak bisa di jadikan jaminan untuk mendapatkan pekerjaan yang sesuai dengan latar belakang dan keinginan. Hal ini terbukti dari tingginya tingkat pengangguran terbuka atau pengangguran akademik yang ada di Indonesia.

Insitut Teknologi Sumatera (ITERA) merupakan lembaga pendidikan tingkat tinggi yang memiliki peran penting dalam mempersiapkan lulusan perguruan tinggi yang berkualitas untuk memenuhi kebutuhan dunia industri. Salah satu perguruan tinggi dengan visi dan misi yang besar pasti membutuhkan sistem lowongan pekerjaan untuk mahasiswa, alumni maupun umum. Hal ini diperlukan mengingat perannya yang sangat penting dalam membantu mahasiswa atau lulusan mendapatkan pekerjaan yang sesuai dengan keterampilan yang diperlukan oleh dunia kerja.

Seiring dengan berjalannya waktu, Institut Teknologi Sumatera (ITERA) telah meluluskan lulusan dengan berbagai keahlian yang dapat bersaing dengan para lulusan-lulusan dari perguruan tinggi lain, akan tetapi hingga saat ini Insitut Teknologi Sumatera (ITERA) belum memiliki sistem yang dapat memberikan informasi lowongan pekerjaan dan pengembangan karir bagi mahasiswa dan alumni yang baru lulus sehingga menyebabkan para lulusan berusaha sendiri dalam menemukan dan mencari lowongan pekerjaan, dan juga membutuhkan waktu untuk mendapatkan pekerjaan impian yang mengakibat alumni yang baru lulus mengangur dalam jangka waktu yang cukup lama. Mahasiswa juga membutuhkan informasi dan gambaran tentang dunia kerja untuk persiapan memasuki dunia kerja, sehingga alumni yang baru lulus tidak bingung dan mempunyai persiapan yang matang. ITERA telah memfasilitasi mahasiswanya untuk mendapatkan pekerjaan dengan mengadakan job fair bagi lulusan, akan tetapi dirasa belum efektif dikarenakan lulusan yang ikut serta didalamnya sedikit, yaitu hanya $40 \%$ dari total lulusan yang berstatus fresh graduate.

Dari uraian singkat di atas menarik untuk melakukan penelitian dan pengembanagn sistem penyediaan informasi lowongan pekerjaan untuk lulusan ITERA berbasis web dan kemudian dilakukan pengujian agar tidak ada kendala saat aplikasi digunakan, oleh karena itu penulis memberikan usulan dangan tema "Pengembangan dan Pengujian Website Career center ITERA" 


\subsection{Identifikasi Masalah}

Berdasarkan latar belakang masalah diatas, peneliti mengidentifikasi masalah yang berhubungan dengan aplikasi informasi lowongan kerja agar tidak menyimpang dari pokok permasalahan yang telah diuraikan, yaitu :

a. ITERA belum mempunyai sistem atau aplikasi yang meyediakan informasi lowongan kerja bagi lulusannya.

b. Penyaluran informasi lowongan pekerjaan kurang terpusat karena penyaluran melalui media sosial dan aplikasi pengirim pesan.

c. Kurangnya partisipasi lulusan dalam mengikuti job fair yang diadakan oleh ITERA.

\subsection{Rumusan Masalah}

Berdasarkan latar belakang dan identifikasi masalah yang telah di uraikan sebelumnya, maka rumusan masalah dalam penelitian ini adalah bagaimana menganalisis, merancang dan membangun aplikasi website career center yang dapat mencari lowongan kerja serta dapat melamar lowongan tersebut berbasis web di lingkungan ITERA.

\subsection{Batasan Masalah}

Dalam pelaksanaan penelitian ini terdapat batasan masalah yang perlu diperhatikan, yaitu pada aplikasi ini hanya sampai pada proses melamar pekerjaan saja tidak sampai pada proses seleksi pencari kerja/kandidat

\subsection{Tujuan Penelitian}

Berdasarkan rumusan masalah di atas, maka didapatkan tujuan dari tugas akhir ini adalah menghasilkan sistem penyedia lowongan pekerjaan yang terintegrasi berbasis web.

\section{METODE PENELITIAN}

\subsection{Analisis Masalah}

Institut Teknologi Sumatera (ITERA) dalam memfasilitasi lulusan/mahasiswa untuk mendapatkan pekerjaan hanya mengandalkan job fair saja, akan tetapi dirasa belum efektif dikarenakan lulusan yang ikut serta masih sedikit. Selain itu untuk mendapatkan pekerjaan lulusan berusaha sendiri dalam mencari lowongan pekerjaan dan membutuhkan waktu dalam mendapatkan pekerjaan impian yang mengakibat lulusan mengangur dalam jangka waktu yang cukup lama. Sampai saat ini di ITERA belum ada sistem yang dapat membantu, mempermudah dan memfasilitasi mahasiswa untuk mendapatkan pekerjaan. Aplikasi tentang informasi lowongan kerja sebelumnya tidak ada di Institut Teknologi Sumatera, untuk itu dibuatkan aplikasinya dalam penelitian ini. Aplikasi yang akan dibuat merupakan sebuah aplikasi website career center berbasis web yang menyediakan informasi lowongan pekerjaan sehingga pengguna nanti dapat masuk, melihat, dan melamar lansung di dalam aplikasi web tersebut. Dengan aplikasi website carreer center ini diharapkan mempermudah lulusan/mahasiswa ITERA dalam mencari informasi lowongan kerja, mendaftar dan melamar lowongan kerja secara lansung.

\subsection{Metode Penelitian}

\subsubsection{Desain Penelitian}

Desain penelitian yang digunakan yaitu perancangan berorientasi objek yang merupakan alat bantu dalam OOD (Object Orienterd Design) dan OOA (Object Oriented Analysis). Dasar pembuatan adalah objek, yang merupakan kombinasi antara struktur data dan perilaku dalam satu entitas. Model berorientasi objek bermanfaat untuk memahami masalah, komunikasi dengan ahli aplikasi, pemodelan suatu organisasi, menyiapkan dokumentasi serta perancangan program dan basis data[6].

\subsubsection{Metode Pengumpulan Data}

Dalam pengembangan sistem/aplikasi tentunya diperlukan jenis data yang akurat sesuai dengan sistem yang akan dikembangkan, oleh karena itu dibutuhkan suatu teknik pengumpulan data yang tepat. Jenis data yang didapatkan kemudian di gunakan dalam tahap analisa dan tahap perancangan[7]. Adapun metode yang digunakan untuk pengumpulan data dan informasi adalah sebagai berikut:

a. Observasi

Metode ini merupakan teknik pengumpulan data yang dilakukan dengan mengamati secara langsung guna memperoleh gambaran yang berhub-ungan dengan sistem lowongan kerja yang pernah dibuat oleh pihak swasta maupun perguruan tinggi. 
b. Wawancara

Dalam hal ini penulis melakukan tanya jawab secara langsung mengenai permasalahan yang akan diteliti kepada pihak bagian akademik ITERA. Wawancara ini bertujuan untuk memperjelas dan meyakinkan atas fakta atau informasi yang diperoleh melalui observasi.

\subsubsection{Metode Pendekatan dan Pengembangan Sistem}

a. Metode pendekatan sistem.

Metode pendekatan yang digunakan adalah metode pendekatan berorientasi objek (Object Oriented). Pendekatan berorientasi objek merupakan cara berfikir baru serta berlogika dalam menghadapi masalahmasalah yang akan di atasi dengan bantuan komputer[8]. OOP mencoba mencoba melihat permasalahan lewat pengamatan dunia nyata dimana setiap objek adalah entitas tunggal yang memiliki kombinasi struktur data dan fungsi tertentu[9]. Pendekatan berorientasi objek terdiri dari analisis berorientasi objek (OOA) dan desain berorientasi objek (OOD). Analisis berorientasi objek (OOA) dimulai dengan menyatakan suatu masalah, analisis membuat suatu model situasi dari dunia nyata, menggambarkan sifat penting. Sedangkan desain berorientasi objek (OOD) merupakan tahap lanjutan setelah (OOA), dimana tujuan sistem di organisasikan kedalam sub-sistem berdasarkan struktur analisis dan arsitektur yang dibutuhkan[10].

b. Metode pengembangan sistem.

Metode pengembangan yang digunakan dalam penelitin ini menggunakan pendekatan objek atau OOAD. Dalam OOAD mencakup analisis dan desain sebuah sistem dengan pendekatan objek, yaitu analisis berorientasi objek (OOA) dan desain berorientasi objek (OOD). OOA adalah metode analisis yang memerika requirement (syarat/keperluan) yang harus dipenuhi sebuah sistem) dari sudut pandang kelaskelas dan objek-objek yang ditemui dalam ruang lingkup perusahaan. Se-dangkan OOD adalah metode untuk mengarahkan arsitektur software yang didasarkan pada manipulasi objek-objek sistem atau sub sistem[10].

\subsubsection{Pengujian Perangkat Lunak}

Pengujian perangkat lunak adalah cara atau teknik untuk menguji perangkat lunak yang mempunyai mekanisme untuk menentukan data uji yang dapat menguji secara lengkap dan dapat menemukan kemungkinan kesalahan yang tinggi. Perangkat lunak dapat diuji dengan dua cara[11], yaitu:

a. Pengujian dengan menggunakan data uji untuk menguji semua elemen pro-gram (data internal, loop, logika, keputusan dan jalur). Data uji didapatkan dengan mengetahui struktur internal (kode sumber) dari perangkat lunak.

b. Pengujian dilakukan dengan mengeksekusi data uji dan mengecek apakah fungsional perangkat lunak bekerja dengan baik. Data uji didapatakan dari spesifikasi perangkat lunak.

Pengujian black box adalah pengujian aspek fundamental sistem tanpa memperhatikan struktur logika internal perangkat lunak. Metode ini digunakan untuk mengetahui apakah perangkat lunak berfungsi dengan benar[12]. Pengujian black box merupakan metode perancangan data uji yang didasarkan pada spesifikasi perangkat lunak. Data uji dieksekusi pada perangkat lunak dan kemudian keluaran dari perangkat lunak dicek apakah telah sesuai dengan yang diharapkan[13]. Pengujian black box berusaha menemukan kesalahan dalam kategori:

a. Fungsi-fungsi yang tidak benar atau hilang.

b. Kesalahan output antarmuka sistem.

c. Kesalahan dalam struktur data atau akses database eksternal.

d. Kesalahan kinerja sistem.

Pengujian white box adalah salah satu cara untuk menguji suatu aplikasi dengan cara melihat modul untuk dapat meneliti dan menganalisa kode dari program yang di buat ada yang salah atau tidak. Kalau modul yang telah dan sudah di hasilkan berupa output yang tidak sesuai dengan yang di harapkan maka akan dikompilasi ulang dan di cek kembali kode-kode tersebut hingga sesuai dengan yang diharapkan. Kasus yang sering menggunakan white box testing akan di uji dengan beberapa tahapan yaitu[14]:

a. Pengujian seluruh keputusan yang menggunakan logikal.

b. Pengujian keseluruhan perulangan yang ada sesuai batasan-batasannya.

c. Pengujian pada struktur data yang sifatnya internal dan yang terjamin validitasnya. 


\section{HASIL DAN PEMBAHASAN}

\subsection{Analisis Kebutuhan}

Berdasarkan analisis masalah yang sudah diuraikan, terdapat beberapa kebutuhan yang dikategorikan menjadi kebutuhan fungsional dan non fungsional untuk merancang aplikasi website career center ITERA, yaitu:

a. Kebutuhan Fungsional

1. Perusahaan mampu mengelola data lowongan pekerjaan yang memiliki fungsi menambah, mengubah, menghapus dan menyimpan data lowongan pekerjaan.

2. Administrator mampu menolak dan merima lowongan pekerjaan yang telah dimasukkan oleh perusahaan.

3. Mampu menampilkan semua informasi lowongan kerja terbaru.

4. Mampu melakukan pencarian lowongan kerja terbaru berdasarkan nama pekerjaan, daerah/tempat tinggal dan nama perusahaan.

5. Mampu menampilkan hasil pencarian lowongan pekerjaan berdasarkan keyword yang dimasukkan.

6. Mampu menampilkan detail informasi lowongan pekerjaan dan detail infromasi tentang perusahaan yang sedang membuka lowongan kerja.

7. Mampu mengirim lamar pekerjaan secara lansung atas lowongan kerja yang di inginkan.

8. Mampu menampilkan informasi pencari kerja yang melamar suatu pekerjaan yang berupa data $\mathrm{CV}$ dan cover letter.

b. Kebutuhan Non Fungsional

1. Keamanan sistem yang dilengkapi dengan password dan level pengguna yang berbeda.

2. Performa sistem yang dapat di jalankan pada semua browser.

\subsection{Desain Perancangan Sistem}

Desain perancangan sistem merupakan bagian dari tahapan sistem yang digunakan. Tahapan ini berfokus pada pemodelan alur sistem dan desain antarmuka. Pemodelan alur sistem menggunakan Unfield Modeling Language (UML) sebagai bahasa pemodelan. Use case diagram merupakan pemodelan untuk kelakuan (behavior) aplikasi yang akan dibuat. Use case mendeskripsikan sebuah interaksi satu atau lebih aktor dengan sistem yang akan dibuat. Use case digunakan untuk mengetahui fungsi apa saja yang ada didalam sebuah sistem dan siapa saja yang berhak menggunakan fungsi-fungsi itu[15]. Aktor yang terlibat pada sistem yang akan dibanguan adalah mahasiswa atau lulusan yang ingin mencari pekerjaan, perusahaan dan super admin.

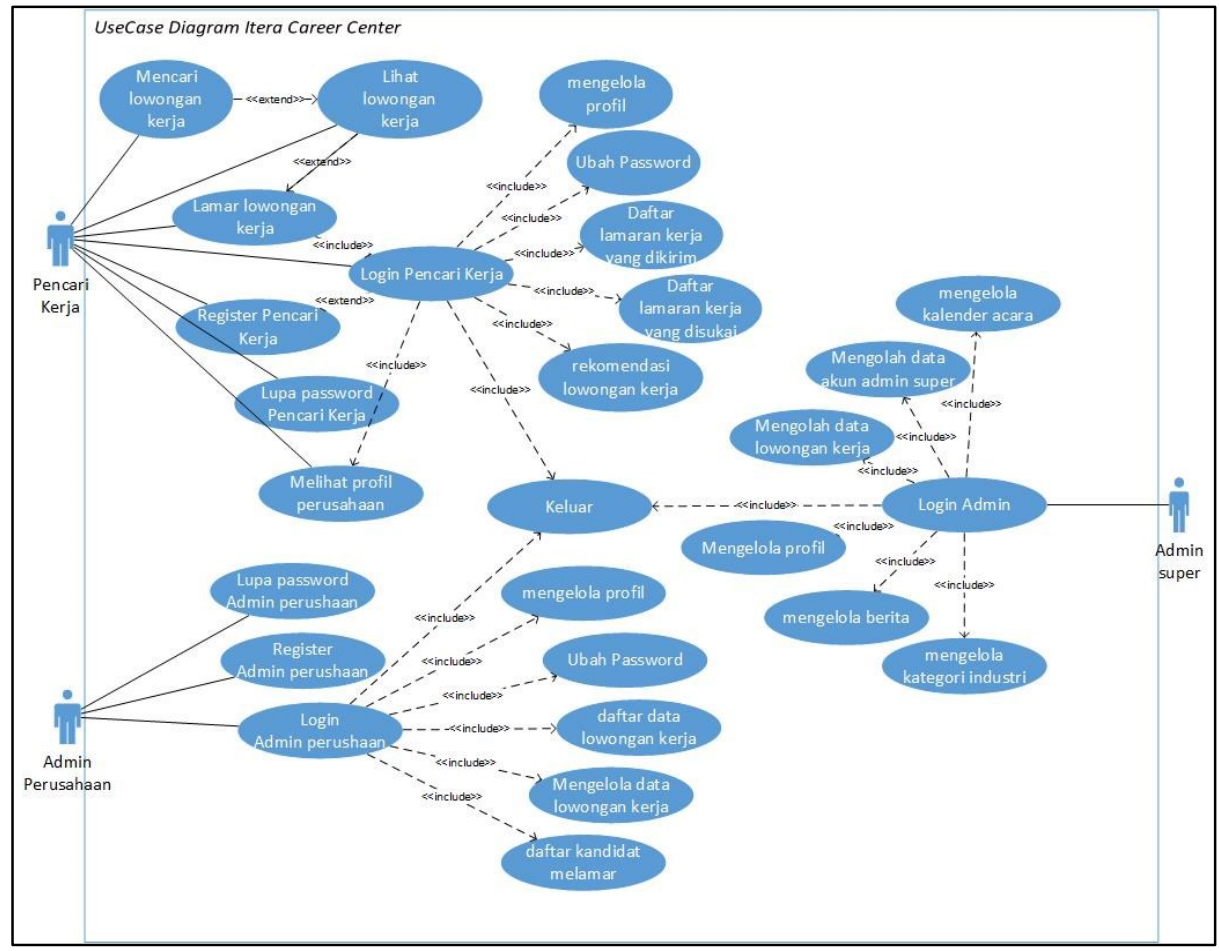

Gambar 1. Use case diagram aplikasi website career center ITERA 


\subsection{Implementasi Sistem}

a. Tampilan antarmuka utama aplikasi

Tampilan utama aplikasi merupakan tampilan yang tampil pertama kali saat aktor pencari kerja membuka website aplikasi ini. Pada tampilan utama terdapat menu, pencarian kerja , kategori pekerjaan, daftar beberapa pekerjaan terbaru, dan footer. Tampilan utama dapat dilihat pada gambar 2 .

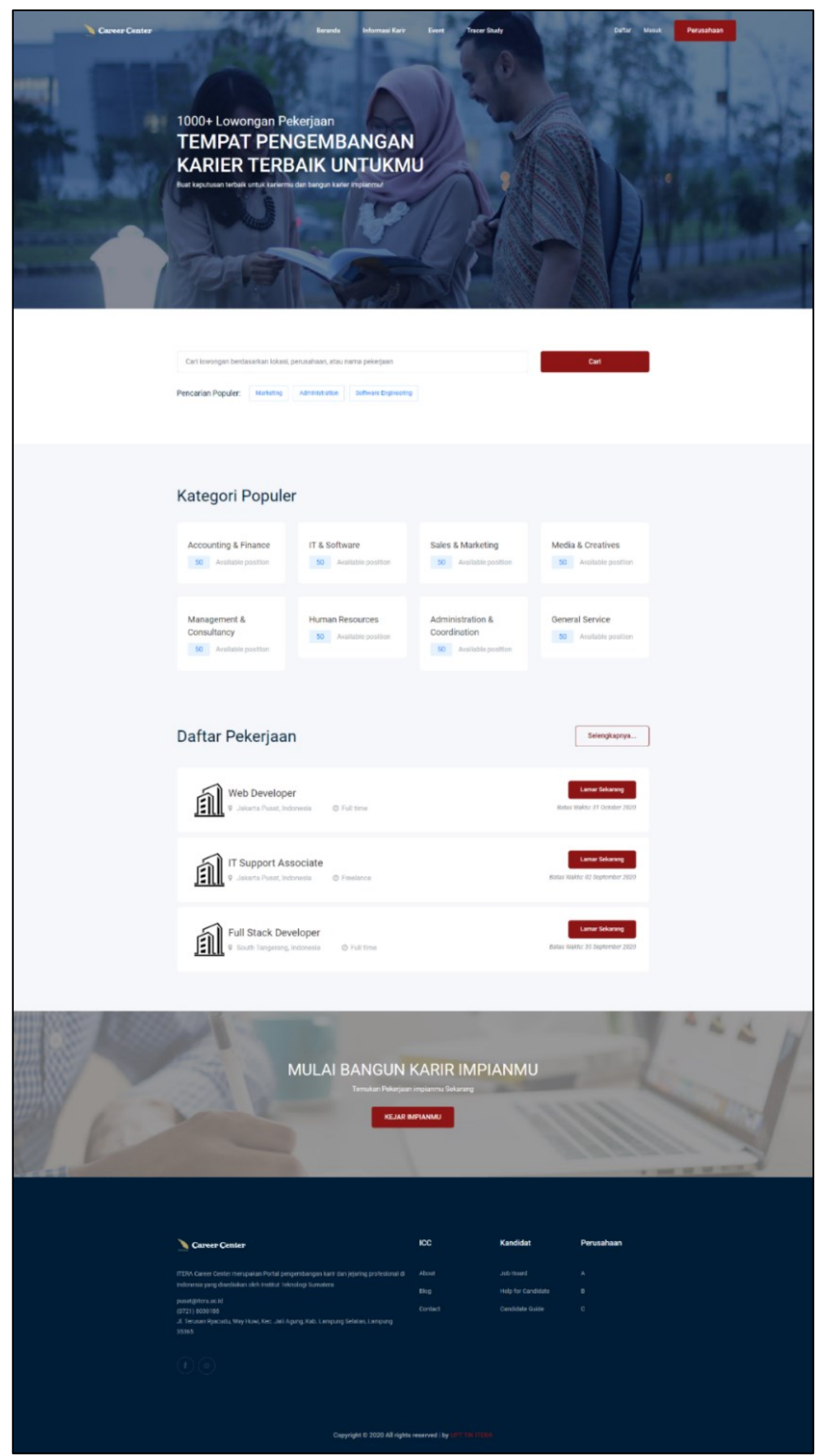

Gambar 2. Tampilan antarmuka utama aplikasi 
b. Tampilan antarmuka dashboard lulusan, pencari kerja atau kandidat.

Tampilan antarmuka dashboard pencari kerja digunakan oleh pengguna yang telah berhasil masuk sebagai pencari kerja. Tampilan antarmuka pencari kerja ini terdapat beberapa menu untuk memanajemeni akun seperti beranda untuk melihat semua daftar lowongan kerja yang dibuka, profil untuk memanajemenkan data diri agar dapat melamar pekerjaan, lamaran berisi daftar lamaran yang pernah dikirim oleh pencari kerja tertentu, pekerjaan disimpan dimana untuk menyimpan peker-jaan yang ingin dilamar nanti, dan rekomendasi pekerjaan. Hasil implementasi tampilan dashboard pencari kerja dapat dilihat pada gambar 3 di bawah ini.

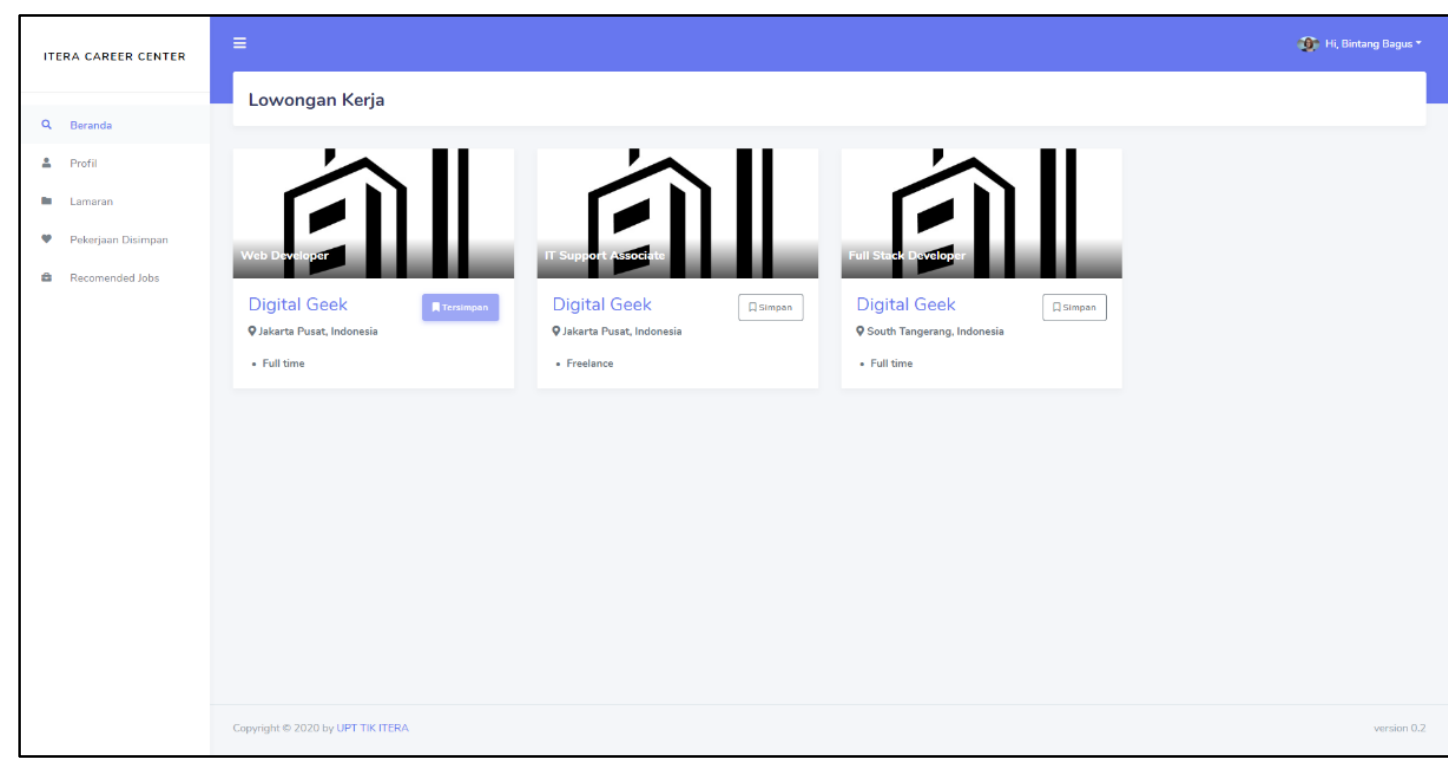

Gambar 3. Tampilan antarmuka dashboard pencari kerja

c. Tampilan antarmuka dashboard perusahaan.

Tampilan dashboard perusahaan digunakan oleh pengguna yang telah berhasil masuk aplikasi sebagai admin perusahaan. Tampilan perusahaan terdapat beberapa menu untuk memanajemeni perusahaan seperti data perusahaan, data penanggung jawab perusahaan pada aplikasi, data pelamar kerja, dan data lowongan pekerjaan. Hasil implementasi tampilan dapat dilihat pada gambar 4 .

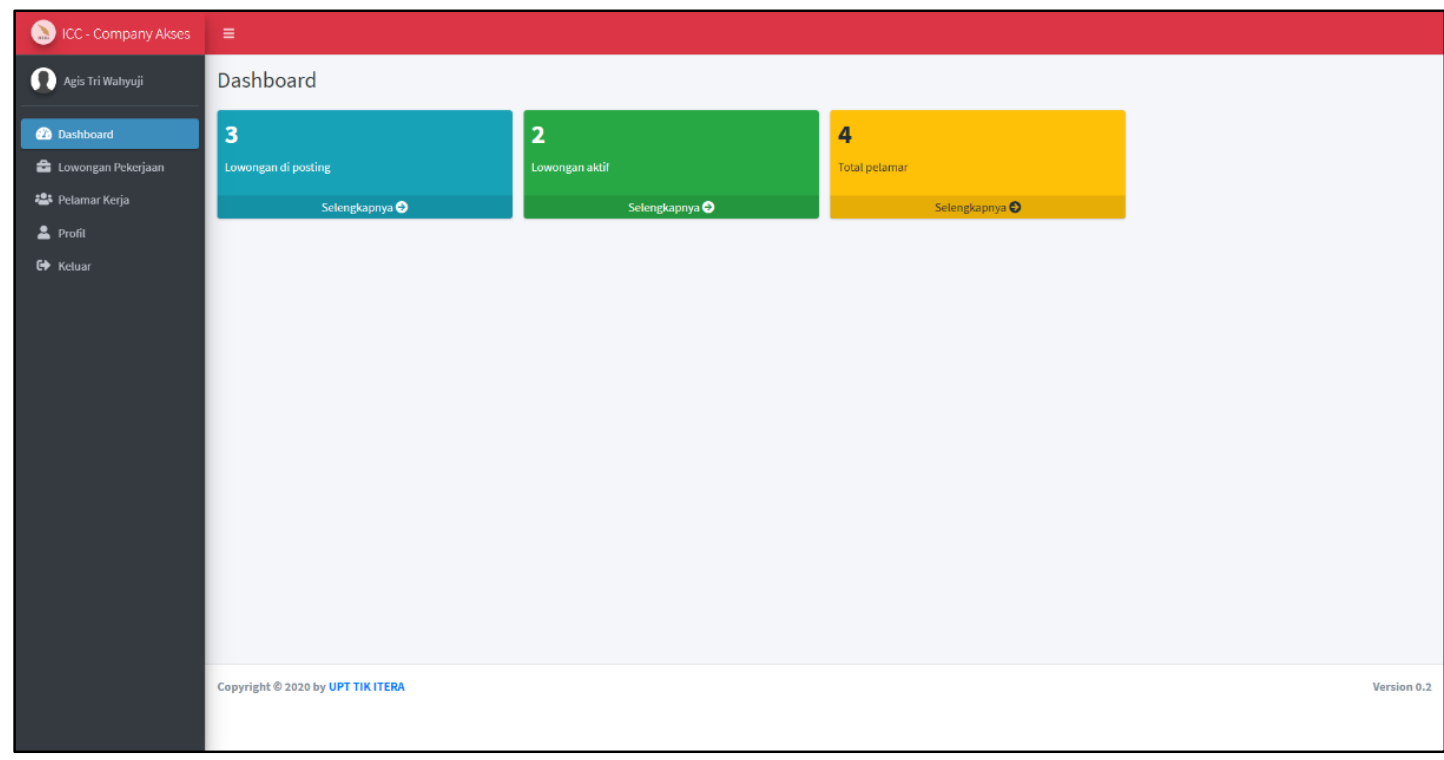

Gambar 4. Tampilan antarmuka dashboard admin perusahaan

d. Tampilan antarmuka dashboard administrator.

Tampilan administrator digunakan oleh pengguna yang telah berhasil masuk sebagai administrator, khusus untuk masuk hanya bisa dilakukan oleh karyawan atau staff yang bertanggung jawab atas aplikasi. Tampilan administrator ini terdapat beberapa menu untuk memanajemeni sistem secara keseluruhan. Hasil implementasi tampilan administrator dapat dilihat pada gambar 5. 


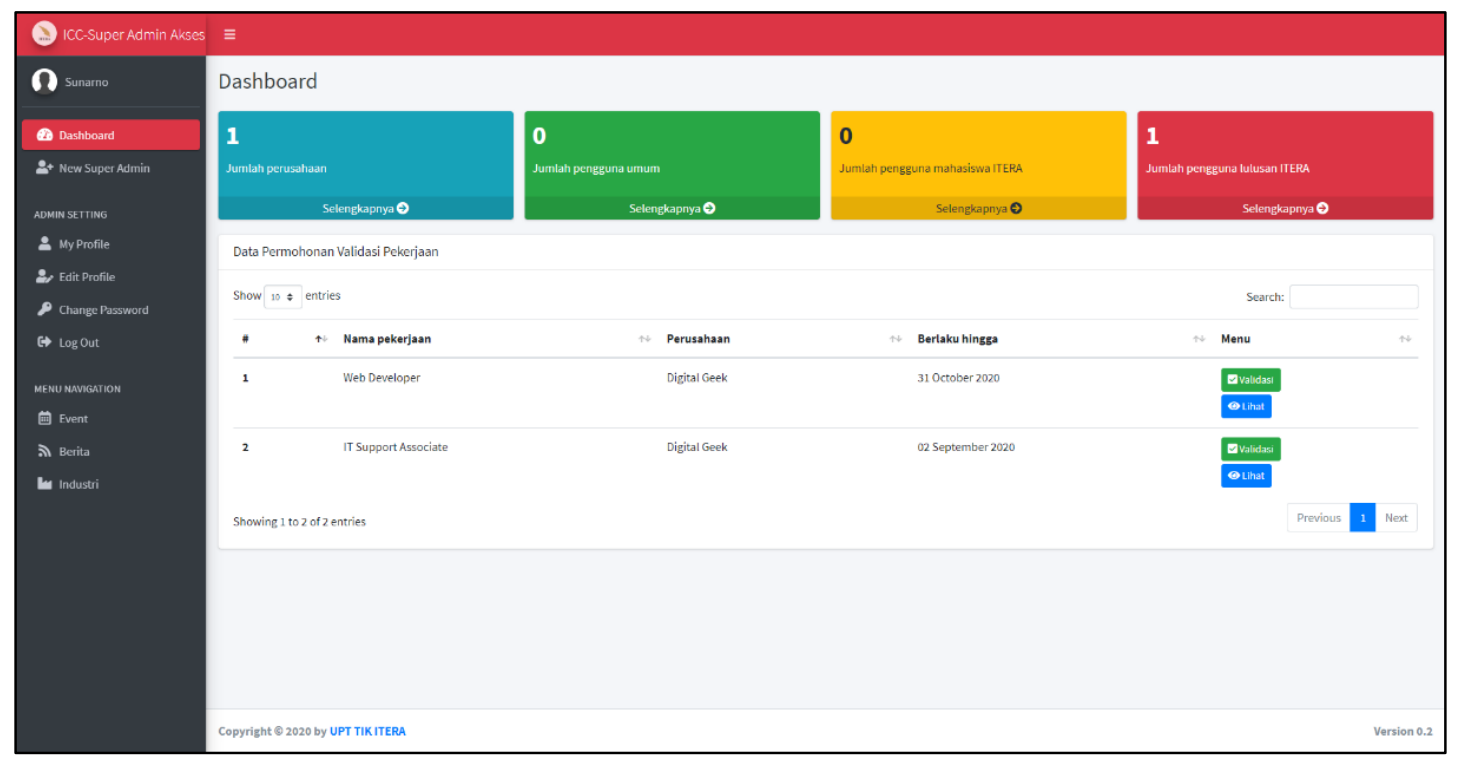

Gambar 5. Tampilan antarmuka dashboard administrator

\subsection{Pengujian Sistem}

a. Pengujian dengan teknik black box testing

Pada tahap ini dilakukan pengujian sistem yang telah diimplementasikan sebelumnya dengan menggunakan pengujian black box. Berikut merupakan hasil pengujian pada aplikasi website career center ITERA.

Tabel 1. Hasil Pengujian black box

\begin{tabular}{|c|c|c|}
\hline \multicolumn{3}{|c|}{ Hasil Pengujian login } \\
\hline Deskripsi Pengujian & Hasil yang diharapkan & Kesimpulan \\
\hline $\begin{array}{l}\text { Mengisi kolom e-mail dengan e-mail dan } \\
\text { kolom password dengan password yang } \\
\text { terdaftar kemudian klik tombol login. }\end{array}$ & $\begin{array}{l}\text { Sistem berhasil masuk kehalaman } \\
\text { dashboard administrator }\end{array}$ & Sesuai \\
\hline $\begin{array}{l}\text { Mengisi kolom e-mail dengan e-mail } \\
\text { yang tak terdaftar dan kolom password } \\
\text { dengan password kemudian klik tombol } \\
\text { login. }\end{array}$ & $\begin{array}{l}\text { Sistem akan menampilkan halaman } \\
\text { login kembali, dengan kesalahan } \\
\text { "Email is not registered!", }\end{array}$ & Sesuai \\
\hline $\begin{array}{l}\text { Mengisi kolom e-mail dengan e-mail } \\
\text { yang terdaftar dan kolom password } \\
\text { dengan password yang salah kemudian } \\
\text { klik tombol login. }\end{array}$ & $\begin{array}{l}\text { Sistem akan menampilkan halaman } \\
\text { login kembali, dengan kesalahan } \\
\text { "Wrong Password!" }\end{array}$ & Sesuai \\
\hline $\begin{array}{l}\text { Tidak Mengisi kolom e-mail dan kolom } \\
\text { password kemudian klik tombol login. }\end{array}$ & $\begin{array}{l}\text { Sistem akan menampilkan halaman } \\
\text { login kembali, dengan memeberikan } \\
\text { pesan kesalahan pada kolom e-mail } \\
\text { "The Email field is required." dan } \\
\text { pesan kesalahan pada kolom } \\
\text { password "The Password field is } \\
\text { required." }\end{array}$ & Sesuai \\
\hline \multicolumn{3}{|c|}{ Hasil Pengujian registrasi akun lulusan, pencari kerja atau kandidat } \\
\hline Deskripsi Pengujian & Hasil yang diharapkan & Kesimpulan \\
\hline $\begin{array}{l}\text { Mengisi semua kolom yang diminta pada } \\
\text { halaman registrasi lulusan, pencari kerja } \\
\text { atau kandidat kemudian klik tombol } \\
\text { daftar. }\end{array}$ & $\begin{array}{l}\text { Sistem mampu menyimpan data ke } \\
\text { dalam database, lalu mengalami } \\
\text { perubahan tampilan menjadi halaman } \\
\text { login, dengan memberikan pesan } \\
\text { bahwa kandidat di haruskan } \\
\text { mangaktifkan akunnya. }\end{array}$ & Sesuai \\
\hline $\begin{array}{l}\text { Mengosongkan pada salah satu kolom } \\
\text { atau lebih kemudian klik tombol daftar. }\end{array}$ & $\begin{array}{l}\text { Sistem menolak untuk menyimpan } \\
\text { data, tampilan tetap pada halaman }\end{array}$ & Sesuai \\
\hline
\end{tabular}


Mengisi semua kolom dengan benar dan data yang sesuai, tetapi mengisika kolom $e$-mail dengan $e$-mail yang pernah sudah diregistrasikan sebelumnya kemudian klik tombol daftar.

Tidak mengisi semua kolom kemudian klik tombol daftar. registrasi akun kandidat dan menampilkan pesan kesalahan pada kolom yang tidak diisi.

Sistem menolak untuk menyimpan data, tampilan tetap pada halaman registrasi akun kandidat dan menampilkan pesan kesalahan "This email has already registered!' pada kolom email.

Sistem akan menampilkan halaman registrasi kembali, dengan memberikan pesan kesalahan pada semua kolom bahwa semua kolom harus diisikan.

\begin{tabular}{|c|c|c|}
\hline \multicolumn{3}{|c|}{ Hasil Pengujian lihat detail perusahaan oleh kandidat } \\
\hline Deskripsi Pengujian & Hasil yang diharapkan & Kesimpulan \\
\hline $\begin{array}{l}\text { Sistem berada pada tampilan data daftar } \\
\text { lowongan pekerjaan kemudian klik } \\
\text { nama perusahaan. }\end{array}$ & $\begin{array}{l}\text { Sistem akan menampilkan semua data } \\
\text { tentang perusahaan secara lengkap. }\end{array}$ & Sesuai \\
\hline \multicolumn{3}{|c|}{ Hasil Pengujian lihat detail perusahaan oleh kandidat } \\
\hline Deskripsi Pengujian & Hasil yang diharapkan & Kesimpulan \\
\hline $\begin{array}{l}\text { Sistem berada pada tampilan data daftar } \\
\text { lowongan pekerjaan kemudian klik } \\
\text { nama posisi pekerjaan. }\end{array}$ & $\begin{array}{l}\text { Sistem akan menampilkan semua } \\
\text { detail data tentang pekerjaan secara } \\
\text { lengkap yang dibuka oleh perusahaan. }\end{array}$ & Sesuai \\
\hline \multicolumn{3}{|c|}{ Hasil Pengujian registrasi akun Perusahaan } \\
\hline Deskripsi Pengujian & Hasil yang diharapkan & Kesimpulan \\
\hline $\begin{array}{l}\text { Mengisi semua kolom yang diminta pada } \\
\text { halaman registrasi perusahaan kemudian } \\
\text { klik tombol daftar. }\end{array}$ & $\begin{array}{l}\text { sistem mampu menyimpan data ke } \\
\text { dalam database, mengalami } \\
\text { perubahan tampilan menjadi halaman } \\
\text { login, dengan memberikan pesan } \\
\text { bahwa perusahaan di haruslkan } \\
\text { mangaktifkan akunnya. }\end{array}$ & Sesuai \\
\hline $\begin{array}{l}\text { Mengosongkan pada salah satu kolom } \\
\text { atau lebih kemudian klik tombol daftar. }\end{array}$ & $\begin{array}{l}\text { Sistem menolak untuk menyimpan } \\
\text { data, tampilan tetap pada halaman } \\
\text { registrasi akun perusahaan dan } \\
\text { menampilkan pesan kesalahan pada } \\
\text { kolom yang tidak diisi. }\end{array}$ & Sesuai \\
\hline $\begin{array}{l}\text { Mengisi semua kolom dengan benar dan } \\
\text { data yang sesuai, tetapi mengisi e-mail } \\
\text { yang pernah diregistrasikan sebelumnya } \\
\text { kemudian klik tombol daftar. }\end{array}$ & $\begin{array}{l}\text { Sistem menolak untuk menyimpan } \\
\text { data dan tampilan tetap pada halaman } \\
\text { registrasi akun perusahaan dan } \\
\text { menampilkan pesan kesalahan "This } \\
\text { email has already registered!" pada } \\
\text { kolom e-mail. }\end{array}$ & Sesuai \\
\hline $\begin{array}{l}\text { Tidak mengisi semua kolom kemudian } \\
\text { klik tombol daftar. }\end{array}$ & $\begin{array}{l}\text { Sistem akan menampilkan halaman } \\
\text { registrasi kembali, dengan } \\
\text { memeberikan pesan kesalahan pada } \\
\text { semua kolom bahwa semua kolom } \\
\text { harus diisi. }\end{array}$ & Sesuai \\
\hline \multicolumn{3}{|c|}{ Hasil Pengujian input data buka lowongan kerja } \\
\hline Deskripsi Pengujian & Hasil yang diharapkan & Kesimpulan \\
\hline $\begin{array}{l}\text { Mengisi semua kolom yang diminta pada } \\
\text { halaman tambah lowongan pekerjaan } \\
\text { kemudian klik tombol tambah. }\end{array}$ & $\begin{array}{l}\text { Sistem mampu menyimpan data } \\
\text { kedalam database dan mengalami } \\
\text { perubahan tampilan menjadi halaman } \\
\text { daftar lowongan pekerjaan dengan } \\
\text { memberikan pesan bahwa proses } \\
\text { tambah lowngan pekerjaan berhasil. }\end{array}$ & Sesuai \\
\hline
\end{tabular}




\begin{tabular}{|c|c|c|}
\hline $\begin{array}{l}\text { Mengosongkan pada salah satu kolom } \\
\text { atau lebih kemudian klik tombol tambah. }\end{array}$ & $\begin{array}{l}\text { Sistem menolak untuk menyimpan } \\
\text { data dan tampilan tetap pada halaman } \\
\text { tambah lowongan pekerjaan dan } \\
\text { menampilkan pesan kesalahan pada } \\
\text { kolom yang tidak diisi. }\end{array}$ & Sesuai \\
\hline $\begin{array}{l}\text { Tidak mengisi semua kolom kemudian } \\
\text { klik tombol daftar. }\end{array}$ & $\begin{array}{l}\text { Sistem menolak untuk menyimpan } \\
\text { data, tampilan tetap pada halaman } \\
\text { tambah lowongan pekerjaan dan } \\
\text { menampilkan pesan kesalahan pada } \\
\text { kolom yang tidak diisi. }\end{array}$ & Sesuai \\
\hline \multicolumn{3}{|c|}{ Hasil Pengujian ubah data lowongan kerja } \\
\hline Deskripsi Pengujian & Hasil yang diharapkan & Kesimpulan \\
\hline \multicolumn{2}{|c|}{$\begin{array}{l}\text { Sistem berada pada tampilan daftar } \\
\text { semua lowongan kerja yang dibuat menampilkan pop-up untuk } \\
\text { kemudian klik tombol edit. }\end{array}$} & Sesuai \\
\hline $\begin{array}{l}\text { Sistem berada pada tampilan form untuk } \\
\text { mengubah data yang dipilih kemudian } \\
\text { ubah data yang ingin diubah lalu klik } \\
\text { tombol update. }\end{array}$ & $\begin{array}{l}\text { Sistem mampu menyimpan data ke } \\
\text { dalam database dan memberikan } \\
\text { pesan bahwa proses ubah data } \\
\text { lowongan pekerjaan berhasil. }\end{array}$ & Sesuai \\
\hline \multicolumn{3}{|c|}{ Hasil Pengujian hapus lowongan kerja } \\
\hline Deskripsi Pengujian & Hasil yang diharapkan & Kesimpulan \\
\hline $\begin{array}{l}\text { Sistem berada pada tampilan daftar } \\
\text { semua lowongan kerja yang dibuat } \\
\text { kemudian klik tombol hapus. }\end{array}$ & $\begin{array}{l}\text { Sistem akan memberikan peringatan } \\
\text { apakah anda yakin ingin menghapus } \\
\text { lowongan. }\end{array}$ & Sesuai \\
\hline \multicolumn{3}{|c|}{ Hasil Pengujian lihat semua kandidat atau pelamar kerja } \\
\hline Deskripsi Pengujian & Hasil yang diharapkan & Kesimpulan \\
\hline $\begin{array}{l}\text { Sistem berada pada tampilan daftar } \\
\text { semua kandidat kemudian klik tombol } \\
\text { download } C V \text {. }\end{array}$ & $\begin{array}{l}\text { Sistem akan secara otomatis } \\
\text { mengunduh } \mathrm{CV} .\end{array}$ & Sesuai \\
\hline
\end{tabular}

\section{download CV.}

Hasil Pengujian unduh cv kandidat atau pelamar kerja

\begin{tabular}{lll}
\hline Deskripsi Pengujian & Hasil yang diharapkan & Kesimpulan \\
\hline $\begin{array}{l}\text { Sistem berada pada tampilan beranda } \\
\text { atau dashboard kemudian klik pelamar } \\
\text { kerja. }\end{array}$ & $\begin{array}{l}\text { Sistem akan menampilkan daftar } \\
\text { semua kandidat yang melamar pada } \\
\text { perusahaan tersebut. }\end{array}$ & Sesuai \\
\hline \multicolumn{4}{c}{ Hasil Pengujian validasai lowongan kerja } & \\
\hline $\begin{array}{l}\text { Dengkripsi Pengujian } \\
\text { utama. }\end{array}$ & $\begin{array}{l}\text { Sistem akil yang diharapkan } \\
\text { bahwa proses validasi pekerjaan } \\
\text { sukses. }\end{array}$ & Kesimpulan \\
\hline
\end{tabular}

\begin{tabular}{|c|c|c|}
\hline \multicolumn{3}{|c|}{ Hasil Pengujian lamar lowongan kerja } \\
\hline Deskripsi Pengujian & Hasil yang diharapkan & Kesimpulan \\
\hline $\begin{array}{l}\text { Sistem berada pada tampilan detail } \\
\text { lowongan pekerjaan kemudian klik } \\
\text { tombol lamar sekarang. Akan ada } \\
\text { tampilan pop-up untuk konfirmasi data } \\
\text { CV, nomor telepon dan Cover letter. } \\
\text { Kandidat diharuskan mengisi cover } \\
\text { letter. Kemudian klik lamar sekarang }\end{array}$ & $\begin{array}{l}\text { Sistem akan menyimpan data lamaran } \\
\text { ke database, kemudian sistem } \\
\text { memberikan pesan bahwa proses } \\
\text { lamar pekerjaan berhasil. }\end{array}$ & Sesuai \\
\hline \multicolumn{3}{|c|}{ Hasil Pengujian tambah akun administrator } \\
\hline Deskripsi Pengujian & Hasil yang diharapkan & Kesimpulan \\
\hline $\begin{array}{l}\text { Mengisi semua kolom yang ada pada } \\
\text { halaman tambah akun kemudian klik } \\
\text { tombol submit. }\end{array}$ & $\begin{array}{l}\text { Sistem mampu menyimpan data } \\
\text { kedalam database dan memberika } \\
\text { pesan bahwa proses tambah akun } \\
\text { berhasil. }\end{array}$ & Sesuai \\
\hline
\end{tabular}




\begin{tabular}{|c|c|c|}
\hline $\begin{array}{l}\text { Mengosongkan kolom pada salah satu } \\
\text { kolomatau lebih kemudian klik tombol } \\
\text { submit. }\end{array}$ & $\begin{array}{l}\text { Sistem menolak untuk menyimpan } \\
\text { data, memberikan pesan kesalahan } \\
\text { pada kolom yang tidak diisi. }\end{array}$ & Sesuai \\
\hline $\begin{array}{l}\text { Tidak mengisi semua kolom kemudian } \\
\text { klik submit. }\end{array}$ & $\begin{array}{l}\text { Sistem menolak untuk menyimpan } \\
\text { data dan memberikan pesan bahwa } \\
\text { proses tambah akun gagal dan semua } \\
\text { kolom harus diisi. }\end{array}$ & Sesuai \\
\hline \multicolumn{3}{|c|}{ Hasil Pengujian edit profil akun administrator } \\
\hline Deskripsi Pengujian & Hasil yang diharapkan & Kesimpulan \\
\hline $\begin{array}{l}\text { Semua kolom telah terisi kemudian klik } \\
\text { submit. }\end{array}$ & $\begin{array}{l}\text { Sistem mampu menyimpan data } \\
\text { kedalam database dan mengalami } \\
\text { perubahan tampilan. }\end{array}$ & Sesuai \\
\hline $\begin{array}{l}\text { Merubah isi kolom nama dan kolom } \\
\text { gambar kemudian klik submit. }\end{array}$ & $\begin{array}{l}\text { Sistem mampu menyimpan data } \\
\text { kedalam database dan mengalami } \\
\text { perubahan tampilan. }\end{array}$ & Sesuai \\
\hline $\begin{array}{l}\text { Merubah isi kolom nama atau kolom } \\
\text { gambar kemudian klik submit. }\end{array}$ & $\begin{array}{l}\text { Sistem mampu menyimpan data } \\
\text { kedalam database dan mengalami } \\
\text { perubahan tampilan. }\end{array}$ & Sesuai \\
\hline \multicolumn{3}{|c|}{ Hasil Pengujian ubah password akun administrator } \\
\hline Deskripsi Pengujian & Hasil yang diharapkan & Kesimpulan \\
\hline $\begin{array}{l}\text { Mengisi semua kolom yang ada pada } \\
\text { halaman ubah password kemudian klik } \\
\text { tombol submit. }\end{array}$ & $\begin{array}{l}\text { Sistem mampu menyimpan data ke } \\
\text { dalam database dan memberika pesan } \\
\text { bahwa proses ubah password berhasil. }\end{array}$ & Sesuai \\
\hline $\begin{array}{l}\text { Mengosongkan pada salah satu kolom } \\
\text { kemudian klik tombol submit. }\end{array}$ & $\begin{array}{l}\text { Sistem menolak untuk menyimpan } \\
\text { data dan memberikan pesan kesalahan } \\
\text { pada kolom yang tidak diisi. }\end{array}$ & Sesuai \\
\hline $\begin{array}{l}\text { Tidak mengisi semua kolom kemudian } \\
\text { klik submit. }\end{array}$ & $\begin{array}{l}\text { Sistem menolak untuk menyimpan } \\
\text { data dan memberikan pesan bahwa } \\
\text { proses ubah password gagal bahwa } \\
\text { semua kolom harus diisi. }\end{array}$ & Sesuai \\
\hline
\end{tabular}

b. Pengujian dengan teknik white box testing

Pengujian dilakukan berdasarkan diagram aktivitas yang telah dijelaskan pada perancangan aplikasi wesite career center ITERA. Setelah diterapkan pengujian dengan teknik white box testing menggunakan tool Katalon Studio menghasilkan rangkuman pengujian sebagai berikut:

Tabel 2. Hasil Pengujian white box dengan Katalon Studio

\begin{tabular}{cccc}
\hline Fungsi & Time Elapsed (Detik) & Test Step & Time Elapsed (Detik) \\
\hline Login pencari kerja & $00: 00: 14.318$ & 12 & $P A S S E D$ \\
\hline Login perusahaan & $00: 00: 13.093$ & 11 & $P A S S E D$ \\
\hline Login administrator & $00: 00: 11.781$ & 10 & $P A S S E D$ \\
\hline Registrasi akun pencari kerja & $00: 00: 17.052$ & 13 & $P A S S E D$ \\
\hline Registrasi akun perusahaan & $00: 00: 15.890$ & 10 & $P A S S E D$ \\
\hline Buka lowongan kerja & $00: 00: 23.563$ & 21 & FAILED \\
\hline Validasi lowongan kerja & $00: 00: 12.091$ & 10 & $P A S S E D$ \\
\hline Lamar pekerjaan & $00: 00: 13.850$ & 12 & $P A S S E D$ \\
\hline Tambah administrator baru & $00: 00: 13.981$ & 13 & $P A S S E D$ \\
\hline Ubah password administrator & $00: 00: 11.776$ & 12 & $P A S S E D$ \\
\hline Edit profil administrator & $00: 00: 12.791$ & 10 &
\end{tabular}




\section{KESIMPULAN}

Berdasarkan hasil implementasi dan pengujian aplikasi website career center ITERA, maka dapat ditarik kesimpulan sebagai berikut:

a. Penelitian ini berhasil merancang, mengembangkan dan membangun aplikasi website career center ITERA dan aplikasi yang dikembangkan dapat membantu pengguna dalam mencari informasi lowongan kerja yang sesuai kebutuhan mereka dan memudahkan mereka untuk lansung mendaftarkan dirinya.

b. Pengujian perangkat lunak menggunakan teknik black box dengan metode Equivalence Partitioning memberikan hasil pengujian terhadap aplikasi website career center ITERA yang diujikan berjalan dengan baik sesuai dengan yang diharapkan. Ini pun membuktikan bahwa metode Equivalence Partitioning dapat digunakan dengan cukup mudah dalam melakukan pengujian aplikasi.

c. Pengujian menggunakan teknik white box dengan tool Katalon Studio, objek yang diujikan sesuai dengan rancangan aktivitas aplikasi. Aplikasi web career center ITERA ketika diuji membutuhkan respone time total 159.4 detik atau rata-rata 14.5 detik dengan hasil yang baik, hanya terdapat 1 kegagalan yaitu tidak bisa menerima masukkan tanggal sehingga aplikasi terdapat kesalahan. Katalon Studio tidak dapat mendeteksi masukkan berupa datepicker pada aplikasi web.

\section{REFERENCES}

[1] I. Khamisah, H. Sujaini, and R. D. Nyoto, "Rancang Bangun Sistem Informasi Career Center Dengan Metode Promethee Berbasis Web,” J. Sist. dan Teknol. Inf., vol. 1, no. 1, pp. 1-6, 2016.

[2] Alvisyahrin, "Pengembangan Sistem Penyedia Informasi Lowongan Kerja Berbasis Website Menggunakan Metode Extreme Programming,” UIN Sunan Kalijaga Yogyakarta, 2018.

[3] Wahyumardi, “Analisis dan Perancangan Sistem Informasi UIN Karir (Studi Kasus Program Studi Sistem Informasi),” Universitas Islam Negeri Syarif Hidayatullah Jakarta, 2011.

[4] J. Hartono, K. Yuliana, L. D. I. Dalam, A. Sistem, I. Fahrurrozi, and A. SN, "Pos Indonesia (Persero) Divisi Regional Vi Semarang,” J. Online STMIK, vol. 1, no. Ii, p. 120, 2016.

[5] R. Ratnasari, "Sistem Informasi Persedian barang pada perumnas regional IV cabang Surapati Bandung," Universitas Komputer Indonesia, 2013.

[6] F. Lesmana, "Sistem Informasi Lowongan Kerja dan Pelacakan Alumni Berbasis Web (Studi Kasus: Fakultas Sains dan Teknologi UIN SUSKA Riau),” Universitas Islam Negeri Sultan Syarif Kasim Riau, 2016.

[7] Asmita Triamalia, "Rancang Bangun Portal Ketenagakerjaan Berbasis Web (Studi Kasus : PT. Bintang Internasional)," UIN Alauddin Makassar, 2017.

[8] H. I. Mukarromah, "Perancangan Aplikasi Sistem Informasi Kepegawaian pada sub bagian Kepegawaian dan Umum BAPPEDA Jawa Barat,” UNIVERSITAS KOMPUTER INDONESIA, 2010.

[9] A. Mujilan, “Analisis Dan Perancangan Sistem,” Univ. Widya Mandala Madiun, pp. 1-22, 2013.

[10] E. Fernandi, F. Alfandri, G. A. P. Putri, and R. Mathias, “Analisis dan Design Berorientasi Objek ( OOAD ) dan Diagram Activity," 2014.

[11] I. Anasruloh, "Pengembangan Sistem Informasi Bursa Kerja Online Berbasis Web di SMK Muhammdiyah 1 Bambanglipuro,” Universitas Negeri Yogyakarta, 2018.

[12] M. Shi, "Software Functional Testing from the Perspective of Business Practice," Comput. Inf. Sci., vol. 3, no. 4, pp. 49-52, 2014, doi: 10.5539/cis.v3n4p49.

[13] U. Hanifah, R. Alit, and S. Sugiarto, "Penggunaan Metode Black Box Pada Pengujian Sistem Informasi Surat Keluar Masuk," SCAN - J. Teknol. Inf. dan Komun., vol. 11, no. 2, pp. 33-40, 2016.

[14] M. Nuris, "White box testing pada sistem penilaian pembelajaran,” UIN Maulana Malik Ibrahim Malang, 2015.

[15] B. A. Purnomo, "Sistem Informasi Bursa Kerja di Pusat Karir dan Pelacakan Alumni Universitas Muria Kudus Berbasis Web," Universitas Muria Kudus, 2014. 